IJJM

Ilomata International Journal of Management

P-ISSN: 2714-8971; E-ISSN: 2714-8963

Vol. 1 No. 4 October 2020 pp.149-158

https://www.ilomata.org/index.php/ijim

\title{
The Effect Of Capital Adequacy Ratio (CAR), Net Interest Margin (NIM), Non-Performing Loan (NPL), and Loan To Deposit Ratio (LDR) Against Return On Asset (ROA) In General Banks In Southeast Asia 2012-2018
}

\author{
Deni Sunaryo \\ Serang Raya University \\ Correspondent: denisunaryomm@gmail.com
}

Submitted : July 16,2020 Revised : September 25, 2020 Published : October 30, 2020

\begin{abstract}
This study aims to determine the effect of Capital Adequacy Ratio (CAR), Net Interest Margin (NIM), Non-Performing Loan (NPL), dan Loan to Deposit Ratio (LDR) in the Return On Asset (ROA) on the Commercial Banks in Southeast Asia in 2012-2018. The independent variable used in this study is Capital Adequacy Ratio (CAR), Net Interest Margin (NIM), Non-Performing Loan (NPL), dan Loan to Deposit Ratio (LDR). The dependent variable used is Return On Assets (ROA). The method used in this study uses purposive sampling technique, using secondary and quantitative data. The results of the analysis show that the data used in this study have met the classical assumption test, multiple regression analysis and hypothesis testing using $\mathrm{t}$ test an $\mathrm{f}$ test and the test the coefficient of determination using SPSS version 23. Based on the results of the study it can be concluded that 1) Capital Adequacy Ratio (CAR) has a positive and significant effect on Return On Asset (ROA). 2) Net Interest Margin (NIM) has a positive and significant effect on Return On Asset (ROA). 3) Non Performing Loan (NPL) no has a positive and significant effect on Return On Asset (ROA). 4) Loan to Deposit Ratio (LDR) has a negative and significant effect on Return On Asset (ROA).

Keyword : Capital Adequacy Ratio (CAR), Net Interest Margin (NIM), Non-Performing Loan (NPL), Loan to Deposit Ratio (LDR), Return On Assets (ROA)
\end{abstract}

\section{INTRODUCTION}

A faster-growing economy makes more capital needed to always improve a country's economy. A company that is engaged in services needs to provide financial services for all levels of society, and the company is known as a bank. The banking industry is one industry that is growing rapidly at this time. Banking is the core of a country's financial system because it plays an active role in supporting the national or regional economy.

The era of globalization is marked by the unification of countries in the world. The opening of world trade and the increasingly widespread development of information technology will affect the world of national banking and economic growth. Regional and international free trade is the beginning of the beginning of the era of economic globalization. On the other hand, banking is a big role because the role of financial institutions is not separated from the other business world besides economic growth will also increase with the cooperation between countries. Countries that are members of the Association of Southeast Asian Nations (ASEAN) consists of 10 countries, namely: Indonesia, Malaysia, the Philippines, Thailand, Myanmar, 
The Effect Of Capital Adequacy Ratio (CAR), Net Interest Margin (NIM), Non-Performing Loan (NPL), and Loan To Deposit Ratio (LDR) Against Return On Asset (ROA) In General Banks In Southeast Asia 2012-2018

Sunaryo

Cambodia, Laos, Vietnam and Brunei Darussalam. ASEAN was formed on August 8, 1967, with the main objective of forming the Southeast Asia region into a safe region (Wahyuni \& Sukirno, 2016).

Return On Assets measure the company's ability to generate net income based on certain asset levels (Hanafi, 2008: 42). Capital Adequacy Ratio (CAR) is a ratio that shows how far the overall bank assets that contain risks (credit, investments, securities, bills at other banks) are also funded from the bank's own capital funds, in addition to funds obtain funds from sources outside the bank, such as public funds, loans (debt), and others (Dendawijaya, 2009: 121). Net Interest Margin (NIM) is a ratio used to measure the ability of bank management in managing their productive assets to generate net interest income derived from interest income less interest expense (Frianto pandia, 2017: 72). Non-Performing Loans (NPL) is a ratio that shows the ability of banks to manage non-performing loans provided by banks. Non-Performing Loans (NPLs) are ratios to measure the level of problem loans that occur at a bank (Hariyani, 2010: 52). The large percentage of NPLs must be a concern of management because the increasing problem loans can endanger the health of the bank. LDR is the ratio of loans to third party funds received by the bank concerned. The amount of LDR will affect the profits through credit creation (Hariyani, 2010: 56).

Based on the explanation above, it can be seen from the level of Capital Adequacy Ratio (CAR), Net Interest Margin (NIM), Non-Performing Loan (NPL), and Loan to Deposit Ratio (LDR) that fluctuations can affect a bank's Return On Assets (ROA). According to Pasaman Silaban (2017) shows that the capital adequacy ratio (CAR) does not have a significant effect on bank profitability. According to Agus Saputra, Muhammad Arfan, Mulia Saputra (2018) in his research showed the Net Interest Margin (NIM) variable had a positive and significant impact on the profitability of Non-Foreign Exchange Commercial Banks. According to Pasaman Silaban (2017) in his research stated that NPL has a negative effect on bank profitability (ROA). According to Ida Bagus Raka Suardana, I Nengah Tie Astawa, Luh Kadek Budi Martini (2017) in his research showed that the Loan to Deposit Ratio (LDR) had a positive effect on Return on Assets (ROA). According to Rahmawati Nur Faizah and Saryadi (2018) Capital Adequacy Ratio (CAR), Loan to Deposit Ratio (LDR), Non-Performing Loan (NPL), and Net Interest Margin (NIM) in their research have a significant effect on ROA simultaneously.

Based on the above research and the phenomena that occur as well as differences in the results of previous studies, profitability is an important issue in banking. Thus the authors conducted further research in this study with the theme "The Effect Of Capital Adequacy Ratio (CAR), Net Interest Margin (NIM), Non-Performing Loan (NPL), And Loan To Deposit Ratio (LDR) On Return On Asset (ROA) In General Banks In Southeast Asia 2012-2018 ".

\section{METHODS}

This research was conducted on banking companies listed on the Southeast Asia Stock Exchange for the period 2012-2018. The study was conducted with a purposive sampling method, which is a sampling method based on certain criteria and considerations. Sample determining criteria:

1. Banks that are categorized as banks into the public that have been listed on the Southeast Asian Stock Exchange from 2012-2018.

2. Registered and remained active in the Southeast Asian banking industry in 2012-2018. 
The Effect Of Capital Adequacy Ratio (CAR), Net Interest Margin (NIM), Non-Performing Loan (NPL), and Loan To Deposit Ratio (LDR) Against Return On Asset (ROA) In General Banks In Southeast Asia 2012-2018

Sunaryo

3. Banks that issue financial reports continuously in the 2012-2018 period and are available in annual financial reports that have been published on the websites of Bank Indonesia, Bank Malaysia, Bank Singapore, Bank of Thailand, and Bank of the Philippines.

4. The bank has complete data needed during the 2012-2018 period, namely the report consisting of balance sheet reports, income statements, financial ratio reports and notes to financial statements that are used as research data.

\section{RESULTS AND DISCUSSION}

Table 1,

Descriptive Statistics Testing Results

Descriptive Statistics

\begin{tabular}{|c|c|c|c|c|c|c|c|c|c|}
\hline & $\mathrm{N}$ & Range & Minimum & Maximum & Sum & \multicolumn{2}{|c|}{ Mean } & Std. Deviation & Variance \\
\hline & Statistic & Statistic & Statistic & Statistic & Statistic & Statistic & Std. Error & Statistic & Statistic \\
\hline CAR & 70 & 11.56 & 11.40 & 22.96 & 1163.22 & 16.6174 & .27500 & 2.30086 & 5.294 \\
\hline NIM & 70 & 13.39 & 1.71 & 15.10 & 291.95 & 4.1707 & .26901 & 2.25067 & 5.066 \\
\hline NPL & 70 & 3.30 & .79 & 4.09 & 154.08 & 2.2011 & .09787 & .81886 & .671 \\
\hline LDR & 70 & 62.93 & 67.80 & 130.73 & 6414.72 & 91.6389 & 1.55783 & 13.03370 & 169.877 \\
\hline ROA & 70 & 4.45 & .70 & 5.15 & 115.68 & 1.6526 & .11759 & .98384 & .968 \\
\hline Valid N (listwise) & 70 & & & & & & & & \\
\hline
\end{tabular}

Source: Data processed by IBM SPSS Statistics 23

Based on table 1, an explanation: Capital Adequacy Ratio (CAR) with a sample of 70 has a minimum value of 11.40 , a maximum value of 22.96, with an average value of 16.6174 and a standard deviation of 2.30086. Net Interest Margin (NIM) with sample 70 has a minimum value of 1.71 , a maximum value of 15.10 , with an average value of 4.1707 and a standard deviation of 2.225067. Non-Performing Loan (NPL) with a sample of 70 has a minimum value of 0.79 , a maximum value of 4.09, with an average value of 2.2011 and a standard deviation of 0.81886 . Loan to Deposit Ratio (LDR) with a sample of 70 has a minimum value of 67.80 , a maximum value of 130.73, with an average value of 91.6389 and a standard deviation of 13.03370. Return On Assets (ROA) with sample 70 has a minimum value of 0.70 , a maximum value of 5.15, with an average value of 1.6526 and a standard deviation of 0.98384 .

Table 2.

Normality Test Results -Kolmogorov Smirnov Test After Transformation

One-Sample Kolmogorov-Smirnov Test

\begin{tabular}{|c|c|c|}
\hline & & $\begin{array}{l}\text { Unstandardiz } \\
\text { ed Residual }\end{array}$ \\
\hline$N$ & & 58 \\
\hline \multirow[t]{2}{*}{ Normal Parameters ${ }^{a, b}$} & Mean & .0000000 \\
\hline & Std. Deviation & .25147273 \\
\hline \multirow[t]{3}{*}{ Most Extreme Differences } & Absolute & .070 \\
\hline & Positive & .070 \\
\hline & Negative & -.060 \\
\hline Test Statistic & & .070 \\
\hline Asymp. Sig. (2-tailed) & & $.200^{c, d}$ \\
\hline
\end{tabular}

a. Test distribution is Normal.

b. Calculated from data.

c. Lilliefors Significance Correction.

d. This is a lower bound of the true significance.

Source: Data processed by IBM SPSS Statistics 23 
The Effect Of Capital Adequacy Ratio (CAR), Net Interest Margin (NIM), Non-Performing Loan (NPL), and Loan To Deposit Ratio (LDR) Against Return On Asset (ROA) In General Banks In Southeast Asia 2012-2018

Sunaryo

After being tested again with the natural logarithmic data transformation tool the results meet the normality standard of data, the Asymp value, sig (2-tailed) exceeds 0.05 . As many as 12 of these tests were lost, so that the new sample was 58. Based on table 4.3 the normality test results above show that the normality test results show a Kolmogorov-Smirnov Z value of 0.070 with a significant value of $0.200>0.05$, it can be concluded that the data used in this study normal distribution data. Can be seen on a normal P-plot graph. Normal distribution will form a diagonal straight line then the line that describes the actual data will follow a diagonal line.

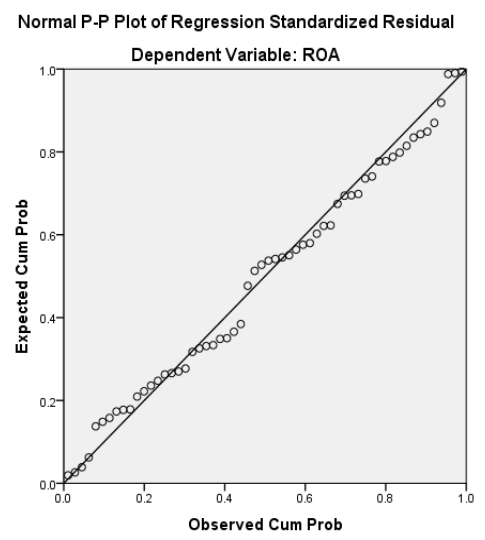

Figure 1

Data Normality Test Results After Transformation

Source: Data processed by IBM SPSS Statistics 23

After the transformation, looking at the P-plot image shows that the point spreads around the diagonal line and follows the direction of the diagonal line that is normally distributed. This shows that the regression model can meet the assumption of normality.

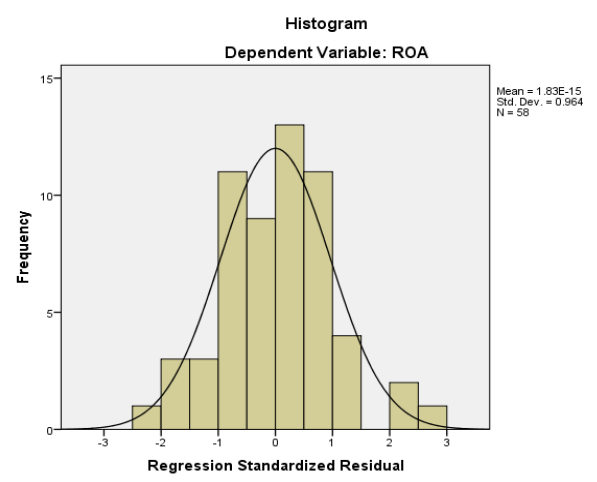

Figure 2.

Data Normality Test Results

Source: Data processed by IBM SPSS Statistics 23

Can be seen from the histogram graph above, shows that the pattern of graphs following the standard form of residuals does not deceive right or left states that the data is normally distributed.

The autocorrelation test results showed a Durbin-Watson (DW) value of 1.981 which indicated that the DW value was between du (1.72594) to 4-du (2.27406). The DW value is in the area of no positive or negative autocorrelation. 
The Effect Of Capital Adequacy Ratio (CAR), Net Interest Margin (NIM), Non-Performing Loan (NPL), and Loan To Deposit Ratio (LDR) Against Return On Asset (ROA) In General Banks In Southeast Asia 2012-2018

Sunaryo

Table 3.

Autocorrelation Test Results

Model Summary ${ }^{\mathrm{b}}$

\begin{tabular}{|l|c|r|r|r|r|}
\hline Model & $\mathrm{R}$ & R Square & \multicolumn{1}{|c|}{$\begin{array}{c}\text { Adjusted R } \\
\text { Square }\end{array}$} & $\begin{array}{c}\text { Std. Error of } \\
\text { the Estimate }\end{array}$ & $\begin{array}{c}\text { Durbin- } \\
\text { Watson }\end{array}$ \\
\hline 1 & $.611^{\mathrm{a}}$ & .373 & .326 & .26079 & 1.981 \\
\hline
\end{tabular}

a. Predictors: (Constant), Ln_LDR, Ln_CAR, NIM, NPL

b. Dependent Variable: ROA

Source: Data processed by IBM SPSS Statistics 23

Therefore it must be supported by the Runs Test Autocorrelation Test. This test is part of non-parametric statistics that can be used to test whether there is a high correlation between residuals. Decision making is done by looking at Asymp. Sig (2-tailed) Runs Test. If the Asymp.Sig (2-tailed) value is greater than the 0.05 significance level, it can be concluded that there is no autocorrelation. The Runs Test will give a more definitive conclusion if a problem occurs in the Durbin Watson Test, namely the value of $\mathrm{d}$ lies between $\mathrm{dl}$ and du which causes no definitive conclusions (Ghazali, 2016). Test Results Runs Test can be seen as follows:

Table 4.

Autocorrelation Test (Runs Test)

Runs Test

\begin{tabular}{|l|r|}
\hline & $\begin{array}{c}\text { Unstandardiz } \\
\text { ed Residual }\end{array}$ \\
\hline Test Value $^{\text {a }}$ & .02131 \\
Cases < Test Value & 29 \\
Cases >= Test Value & 29 \\
Total Cases & 58 \\
Number of Runs & 33 \\
Z & .795 \\
Asymp. Sig. (2-tailed) & .427 \\
\hline
\end{tabular}

a. Median

Source: Data processed by IBM SPSS Statistics 23

The autocorrelation test results showed that the value of asymp sig 2 tailed from the run test was 0.427 which was greater than 0.05 . meaning that there is no autocorrelation problem.

Table 5.

Multicorrelation Test Results

\begin{tabular}{|c|c|c|c|c|c|c|c|c|}
\hline \multicolumn{9}{|c|}{ Coefficients $^{a}$} \\
\hline \multirow[b]{2}{*}{ Mod } & & \multicolumn{2}{|c|}{ Unstandardized Coefficients } & \multirow{2}{*}{$\begin{array}{c}\begin{array}{c}\text { Standardized } \\
\text { Coefficients }\end{array} \\
\text { Beta }\end{array}$} & \multirow[b]{2}{*}{$\mathrm{t}$} & \multirow[b]{2}{*}{ Sig. } & \multicolumn{2}{|c|}{ Collinearity Statistics } \\
\hline & & $B$ & Std. Error & & & & Tolerance & VIF \\
\hline \multirow[t]{5}{*}{1} & (Constant) & -.554 & 1.578 & & -.351 & .727 & & \\
\hline & Ln_CAR & .703 & .318 & .266 & 2.208 & .032 & .814 & 1.228 \\
\hline & NIM & .128 & .031 & .499 & 4.195 & .000 & .835 & 1.198 \\
\hline & NPL & .024 & .050 & .067 & .477 & .636 & .604 & 1.655 \\
\hline & Ln_LDR & -.139 & .289 & -.063 & -.479 & .634 & .690 & 1.450 \\
\hline
\end{tabular}

Source: Data processed by IBM SPSS Statistics 23 
The Effect Of Capital Adequacy Ratio (CAR), Net Interest Margin (NIM), Non-Performing Loan (NPL), and Loan To Deposit Ratio (LDR) Against Return On Asset (ROA) In General Banks In Southeast Asia 2012-2018

Sunaryo

Based on table 4 above, it can be seen that all independent variables, namely CAR, NIM, NPL, and LDR have a tolerance value greater than 0.10 and a VIF value smaller than 10 . This means that there is no multicollinearity, so data is good to use in the regression model.

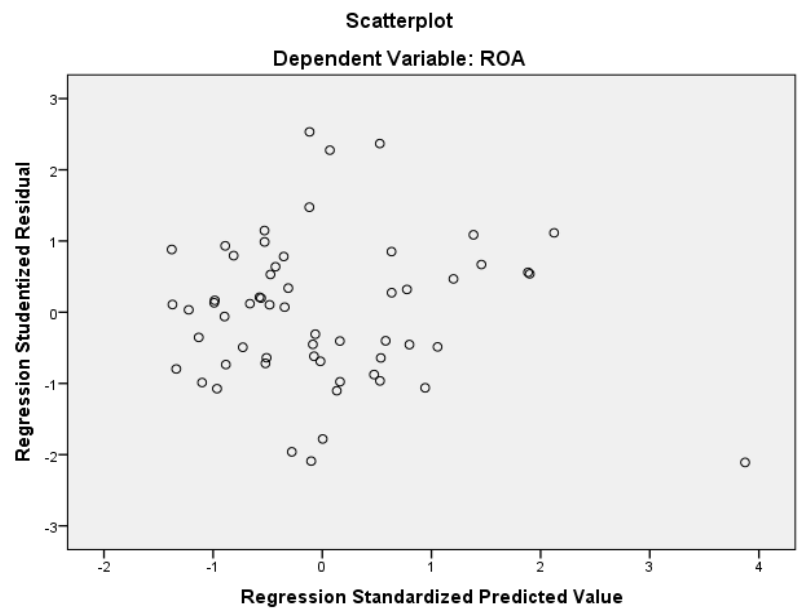

Figure 3

Heteroscedasticity Test Results

Source: Data processed by IBM SPSS Statistics 23

Based on Figure 3 it can be seen that the residual data in both regression models spread both above and below the 0 point on the $\mathrm{Y}$ axis and do not form a certain pattern. Thus the regression model proposed in this study does not occur heteroskedasticity symptoms to produce ROA.

Table 6.

Multiple Linear Regression Test Results

Coefficients $^{\mathrm{a}}$

\begin{tabular}{|c|c|c|c|c|c|c|c|c|}
\hline \multirow[b]{2}{*}{ Mode } & & \multicolumn{2}{|c|}{ Unstandardized Coefficients } & \multirow{2}{*}{$\begin{array}{c}\begin{array}{c}\text { Standardized } \\
\text { Coefficients }\end{array} \\
\text { Beta }\end{array}$} & \multirow[b]{2}{*}{$t$} & \multirow[b]{2}{*}{ Sig. } & \multicolumn{2}{|c|}{ Collinearity Statistics } \\
\hline & & $B$ & Std. Error & & & & Tolerance & VIF \\
\hline \multirow[t]{5}{*}{1} & (Constant) & -.554 & 1.578 & & -.351 & .727 & & \\
\hline & Ln_CAR & .703 & .318 & .266 & 2.208 & .032 & .814 & 1.228 \\
\hline & NIM & .128 & .031 & .499 & 4.195 & .000 & .835 & 1.198 \\
\hline & NPL & .024 & .050 & .067 & .477 & .636 & .604 & 1.655 \\
\hline & Ln_LDR & -.139 & .289 & -.063 & -.479 & 634 & .690 & 1.450 \\
\hline
\end{tabular}

a. Dependent Variable: ROA

Source: Data processed by IBM SPSS Statistics 23

Based on the results of multiple linear regression in table 6 , the multiple linear regression equation can be explained through the following equation:

$$
\begin{gathered}
\mathrm{Y}=\mathrm{a}+\left(b_{1} \cdot x_{1}\right)+\left(b_{2} \cdot x_{2}\right)+\left(b_{3} \cdot x_{3}\right)+\mathrm{e} \\
\mathrm{ROA}=-0,554+(0,703)+(0,128)+(0,24)+(-0,139)+\mathrm{e}
\end{gathered}
$$

Based on the equation of multiple linear regression can be interpreted as follows:

1. Constants show values of -0.554 meaning that if CAR (X1), NIM (X2), NPL (X3), and $\mathrm{LDR}(\mathrm{X} 4)$ value is 0 , then $\mathrm{ROA}(\mathrm{Y})$ is -0.554 . 
The Effect Of Capital Adequacy Ratio (CAR), Net Interest Margin (NIM), Non-Performing Loan (NPL), and Loan To Deposit Ratio (LDR) Against Return On Asset (ROA) In General Banks In Southeast Asia 2012-2018

Sunaryo

2. CAR Variable Coefficient $=0.703$, means that every $1 \%$ increase in CAR will cause an increase in ROA of $0.703 \%$.

3. The variable coefficient of NIM $=0.128$, means that every $1 \%$ increase in NIM will cause an increase in ROA of $0.128 \%$.

4. NPL variable coefficient of 0.024 means that if the NPL has increased by $1 \%$. Then ROA will increase by $0.024 \%$.

5. LDR Variable Coefficient $=-0.139$, meaning that an increase in LDR of $1 \%$ will cause a decrease in ROA of $0.139 \%$.

Table 7.

Partial Significant Test (t-Test)

\begin{tabular}{|c|c|c|c|c|c|c|}
\hline & & \multicolumn{5}{|c|}{ Coefficients $^{a}$} \\
\hline \multirow{2}{*}{\multicolumn{2}{|c|}{ Model }} & \multicolumn{2}{|c|}{ Unstandardized Coefficients } & \multirow{2}{*}{$\begin{array}{c}\begin{array}{c}\text { Standardized } \\
\text { Coefficients }\end{array} \\
\text { Beta }\end{array}$} & \multirow[b]{2}{*}{$\mathrm{t}$} & \multirow[b]{2}{*}{ Sig. } \\
\hline & & $B$ & Std. Error & & & \\
\hline \multirow[t]{5}{*}{1} & (Constant) & -.554 & 1.578 & & -.351 & .727 \\
\hline & Ln_CAR & .703 & .318 & .266 & 2.208 & .032 \\
\hline & NIM & .128 & .031 & .499 & 4.195 & .000 \\
\hline & NPL & .024 & .050 & .067 & .477 & .636 \\
\hline & Ln_LDR & -.139 & .289 & -.063 & -.479 & .634 \\
\hline
\end{tabular}

a. Dependent Variable: ROA

Source: Data processed by IBM SPSS Statistics 23

1. Capital Adequacy Result (CAR)

Based on SPSS 23 calculations, it can be seen that the t-count of the Capital Adequacy Ratio (CAR) is 2.208 while the size of the t-table with a confidence level $\alpha=0.05$ is 2.00575 and the significance level is $0.032<0.05$, it can be concluded that the Capital Adequacy variable Ratio (CAR) has a positive and significant effect on Return On Assets (ROA) at Commercial Banks in Southeast Asia in 2012-2018.

2. Net Interest Margin (NIM)

Based on SPSS 23 calculation, it can be seen that the t-count of the Net Interest Margin (NIM) is 4.195 while the size of the t-table with a confidence level $\alpha=0.05$ is 2.00575 and the significance level is $0.000<0.05$, it can be concluded that the Net Interest Margin variable ( NIM) has a positive and significant effect on Return On Assets (ROA) at Commercial Banks in Southeast Asia in 2012-2018.

3. Non-Performing Loan (NPL)

Based on SPSS 23 calculation, it can be seen that the non-performing loan (NPL) t-count value is 0.477 while the value of $\mathrm{t}$-table with confidence level $\alpha=0.05$ is 2.00575 and the significance level is $0.636>0.05$, so it can be concluded that the Non-Performing Loan variable ( NPL) does not have a positive and significant effect on Return On Assets (ROA) at Commercial Banks in Southeast Asia in 2012-2018.

4. Loan to Deposit Ratio (LDR)

Based on SPSS 23 calculations, it can be seen that the value of the t-count of the Loan to Deposit Ratio (LDR) is -0.479 while the magnitude of the t-table with a confidence level $\alpha=0.05$ is 2.00575 and the significance level is $0.634>0.05$, it can be concluded whereas the Loan to Deposit Ratio (LDR) variable has no negative and significant effect on Return On Assets (ROA) at Commercial Banks in Southeast Asia in 2012-2018. 
The Effect Of Capital Adequacy Ratio (CAR), Net Interest Margin (NIM), Non-Performing Loan (NPL), and Loan To Deposit Ratio (LDR) Against Return On Asset (ROA) In General Banks In Southeast Asia 2012-2018

Sunaryo

Table 8.

Simultaneous Significance Tests (F-Test)

ANOVA ${ }^{\mathrm{a}}$

\begin{tabular}{|ll|r|r|r|r|l|}
\hline \multicolumn{2}{|l|}{ Model } & \multicolumn{1}{c|}{$\begin{array}{c}\text { Sum of } \\
\text { Squares }\end{array}$} & \multicolumn{1}{c|}{$\mathrm{df}$} & Mean Square & $\mathrm{F}$ & Sig. \\
\hline 1 & Regression & 2.144 & 4 & .536 & 7.880 & $.000^{\mathrm{b}}$ \\
& Residual & 3.605 & 53 & .068 & & \\
& Total & 5.748 & 57 & & & \\
\hline
\end{tabular}

a. Dependent Variable: ROA

b. Predictors: (Constant), Ln_LDR, Ln_CAR, NIM, NPL

Source: Data processed by IBM SPSS Statistics 23

F-test results show that the calculated $\mathrm{F}$ value is greater than the $\mathrm{F}$-table value of $7.880>$ 2.55, and the significance value is smaller than $0.05(0.000<0.05)$. So that $\mathrm{Ho}$ is rejected and $\mathrm{Ha}$ is accepted or it can be concluded that the Capital Adequacy Ratio (CAR), Net Interest Margin (NIM), Non-Performing Loan (NPL) and Loan to Deposit Ratio (LDR) variables simultaneously have a significant effect on Return On Assets (ROA)

Table 9.

Determination Coefficient Test Result $\mathrm{R}^{2}$

Model Summary ${ }^{\mathrm{b}}$

\begin{tabular}{|l|l|r|r|r|}
\hline Model & $\mathrm{R}$ & $\mathrm{R}$ Square & $\begin{array}{c}\text { Adjusted R } \\
\text { Square }\end{array}$ & $\begin{array}{c}\text { Std. Error of } \\
\text { the Estimate }\end{array}$ \\
\hline 1 & $.611^{\mathrm{a}}$ & .373 & .326 & .26079 \\
\hline
\end{tabular}

a. Predictors: (Constant), Ln_LDR, Ln_CAR, NIM, NPL

b. Dependent Variable: ROA

Source: Data processed by IBM SPSS Statistics 23

From the table above it can be seen that the value of Adjusted $\mathrm{R}^{2}$ reflects the ability of the independent variable to explain the related variable. From the SPSS output the size of R square is 0.373 or $37.3 \%$. This value shows that $37.3 \%$ of the variation in the value of the Capital Adequacy Ratio, Net Interest Margin, Non-Performing Loans and Loan to Deposit Ratio, while the remaining $62.7 \%$ is influenced by other variables outside this study. for example Third Party Funds (DPK), company size (Size), Operational Costs to Operating income (BOPO) and others.

\section{CONCLUSION}

Based on the results of the t test of the Capital Adequacy Ratio (CAR) with a significant level of $0.032<0.05$, so partially the Capital Adequacy Ratio (CAR) has a positive and significant effect on Return on Assets (ROA). Net Interest Margin (NIM) variable with a significant level of $0,000<0.05$, then partially the Net Interest Margin (NIM) has a positive and significant effect on Return On Assets (ROA). Non-Performing Loan (NPL) variable with a significant level of $0.636>0.05$, then partially the Non-Performing Loan (NPL) has no positive and significant effect on Return On Assets (ROA). Loan to Deposit Ratio (LDR) variable with a significant level of $0.634>0.05$, then the partial Loan to Deposit Ratio (LDR) has a negative and significant effect on Return on Assets (ROA).

Based on the results of the F Test with a significant level of $0,000>0.05$, simultaneously Capital Adequacy Ratio (CAR), Net Interest Margin (NIM), Non-Performing Loan (NPL) and Loan to Deposit Ratio (LDR) significantly influence the Return On Asset (ROA). 
The Effect Of Capital Adequacy Ratio (CAR), Net Interest Margin (NIM), Non-Performing Loan (NPL), and Loan To Deposit Ratio (LDR) Against Return On Asset (ROA) In General Banks In Southeast Asia 2012-2018

Sunaryo

\section{REFERENCES}

Amaliah, Rifqah S. Hafinaz Hasniyanti Hassan. (2019). "Hubungan antara Risiko Kredit Bank, Likuiditas, dan Kecukupan Modal terhadap Profitabilitas di Indonesia". International Journal of Recent Technology and Engineering (IJRTE) ISSN: 2277-3878, Volume-7 Issue-5S, January 2019.

Ariyanto, Taufik. (2011). "Faktor Penentu Net Interest Margin Perbankan Indonesia". Finance and Banking Journal, Vol. 13 No. 1.

Dendawijaya, Lukman. (2009). Manajemen Perbankan. Edisi kedua. Bogor.: Ghalia Indonesia

Fahmi, Irham (2014). Penghantar Perbankan Teori dan Aplikasi. Bandung: ALFABETA.

Faizah, Rahmawati Nur. Saryadi. (2018). "Pengaruh Capital Adequacy Ratio (CAR), Loan to Deposit Ratio (LDR), Non-Performing Loan (NPL), dan Net Interest Margin (NIM) Terhadap Return On Asset (ROA) (Studi pada Bank Umum dengan Metode Konvensional yang terdaftar di Bursa Efek Indonesia Tahun 2016)". Diponogoro Journal Of Management.

Gani, Ghonio Mohammad (2017). "Pengaruh Return on Assets (ROA) and Return on Equity (ROE) Terhadap Harga Saham pada Perusahaan Manufaktur yang Terdaftar di ASEAN Periode 2013-2015". 2 Jurnal Profita Edisi 4.

Ghozali, Imam. (2016). Aplikasi Analisis Multivariete dengan Program IBM SPSS 23 (Cetakan VIII). Badan Penerbit Universitas Diponegoro.

Hariyani, Iswi. (2010). Restrukturasi dan Penghapusan Kredit Macet. Jakarta: PT. Elex Media Komputindo.

Hasan, Haris ahmad. (2016). "Analisis ASEAN Banking Integration Framework (ABIF) untuk kinerja perbankan di ASEAN (studi perbankan pada Filipina, Indonesia, Malaysia, Singapura dan Thailand Tahun 2012-2014). Jurnal Administrasi Bisnis (JAB) Vol. 34. No. 1 Mei 2016.

Kasmir. (2015). Manajemen Perbankan. Edisi revisi. Jakarta: PT. Raja Grafindo Persada.

Kusmayadi, Dedi. (2018). "Analisis Pengaruh Rasio Kecukupan Modal, Rasio Loan to Deposit, Non-Performing Loan, BOPO, dan Ukuran Pengembalian Aset di Bank Perkreditan Rakyat di Jakarta Indonesia". Saudi Journal of Business and Management Studies (SJBMS).

Sugiyono (2015). Metode Penelitian Kuantatif Kualitatif dan R\&D. Bandung: Alfabeta.

Pandia, Frianto. (2017). Manajemen Dana dan Kesehatan Bank. Jakarta: Rineka Cipta.

Pangestika, C. Zelin Winda Ayu (2018). "Pengaruh DPK, CAR, dan NPL Melalui LDR sebagai Variabel Intervening Terhadap Profitabilitas Bank (Studi pada Bank Terbesar di Asia Tenggara Periode 2012-2016)”. Jurnal Ilmu Manajemen Volume 6 Nomor 3.

Putriningsih, Dwi Indah \& Arief Yulianto (2016). "Pengaruh Non-Performing Loan (NPL) dan Capital Adequacy Ratio (CAR) Terhadap Profitabilitas”. Management Analysis Journal 5 (2).

Rismawati. (2016). "Menghadapi Qualified ASEAN Bank, Indonesia: Berekspansi atau Bertahan di Dalam Negeri?".

Romdani, Bayu Purnama \& Hendry Cahyono (2016). "Pengaruh Net Interest Margin dan Inflasi Terhadap Penyaluran Kredit di Indonesia pada Bank Umum di Indonesia". Jurnal Pendidikan Ekonomi (JUPE). Volume 4 No 3 edisi Yudisium.

Saputra, Agus. Muhammad \& Arfan Mulia Saputra. (2018). "Pengaruh Capital Adequacy Ratio,Net Interest Margin, Loan to Deposit Ratio dan Non performing Loan Terhadap Profitabilitas Bank 
The Effect Of Capital Adequacy Ratio (CAR), Net Interest Margin (NIM), Non-Performing Loan (NPL), and Loan To Deposit Ratio (LDR) Against Return On Asset (ROA) In General Banks In Southeast Asia 2012-2018

Sunaryo

Umum Non Devisa di Indonesia Periode 2014-2016". Jurnal Perspektif Ekonomi Darussalam Volume 4 Nomor 2, September 2018 ISSN. 2502-6976.

Sari, Mutia. Edi Zulfiar (2017). "Pengaruh Loan to Deposit Ratio, Non-Performing Loan, dan Return On Assets Terhadap Capital Adequacy Ratio pada Bank Pembangunan Daerah di Indonesia”. Jurnal Akuntansi dan Pembangunan Volume 3 Nomor 1.

Septiani, Rita (2016). "Pengaruh NPL dan LDR tehadap Profitabilitas dengan CAR sebagai Variabel Mediasi pada PT. BPR PASARRAYA KUTA”. E-Jurnal Manajemen Unud, Vol. 5 No. 1 ISSN: 2302-8912.

Silaban, Pasaman (2017). "Pengaruh Rasio Kecukupan Modal, Margin Bunga Bersih, dan Non Performing Loans terhadap Profitabilitas Bank: Kasus di Indonesia”. International Journal of Economics and Business Administration Volume V, Issue 3, 2017.

Sofyan, M., 2019. ANALYSIS FINANCIAL PERFORMANCE OF RURAL BANKS IN INDONESIA. International Journal of Economics, Business and Accounting Research (IJEBAR), 3(3), pp. 255-262.

Suardana, Ida Bagus Raka. I Nengah Dasi Astawa, Luh Kadek Budi Martini. (2017). "Faktorfaktor yang Berpengaruh terhadap Return On Asset dan Perubahan Laba (Studi pada semua BPR di Provinsi Bali)". International Journal of Social Sciences and Humanities Vol. 2 No. 1, ISSN: 2550-7001, p-ISSN: 2550-701.

Wahyuni, Anggun. (2016). "Analisis Perbandingan Kinerja Keuangan Perbankan ASEAN (Studi pada Bank Umum Indonesia, Thailand dan Filipina Tahun 2011-2014)”. Jurnal Nominal/Volume V Nomor 2/Tahun 2016.

Wahyuningsih, Tri. Abrar Oemar. Agus Suprijanto (2015). "Pengaruh CAR, NPF, FDR, BOPO, dan GWM Terhadap Laba Perusahaan (ROA) pada Bank Umum Syariah di Indonesia Periode 2010-2015".

www.bursamalaysia.com (Bursa Malaysia diakses pada tahun 2019)

www.idx.com (Bursa Efek Indonesia diakses pada tahun 2019)

www.pse.com.ph (Bursa Filipina diakses pada tahun 2020)

www.set.or.th (Bursa Thailand diakses pada tahun 2020)

www.sgx.com (Bursa Singapura diakses pada tahun2019)

https://www.cnbcindonesia.com/market/20180913100121-17-32874/moodys likuiditas-di-asiamasih-ketat (Diakses pada Mei 2020).

https://databoks.katadata.co.id/datapublish/2017/05/15/2016-npl-perbankan-indonesiacukup-tinggi (Diakses pada Mei 2020).

https://databoks.katadata.co.id/datapublish/2019/04/26/3-bank-indonesia-masuk-daftar-bankdengan-kapitalisasi-terbesar-di-asean (Diakses pada Desember 2019).

https://www.google.com/amp/amp.kontan.co.id/news/car-perbankan-di-indonesia-palingtinggi-di-asia-baik-atau-buruk (Diakses pada Juni 2020).

https://www.google.com//amp/amp.kontan.co.id/news/diramal-akan-naik-roa-bank-diindonesia-jadi-yang-paling-tinggi-se-asia-tenggara (Diakses Juni 2020).

https://www.google.com/amp/amp.kontan.co.id/news/penurunan-margin-bunga-bersihmerata-di-asia-tenggara (Diakses pada Juni 2020). 